Servicio de publicaciones y difusión científica (SPDC), Universidad de Las Palmas de Gran Canaria, Parque CientíficoTecnológico, Edificio Polivalente II, C/ Practicante Ignacio Rodríguez, s/n Campus Universitario de Tafira 35017 - Las Palmas de Gran Canaria, Spain.

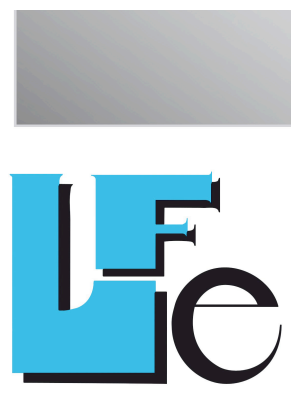

Revista de Lenguas para Fines Específicos

\section{Revista de lenguas} para fines específicos

\author{
elSSN: 2340-8561
}

Journal information, indexing and abstracting details, archives, and instructions for submissions:

https://ojsspdc.ulpgc.es/ojs/index.php/LFE/index

\section{Foreign language learning needs in higher education: Reasons for convergence and accountability}

Ana Bocanegra-Valle

Universidad de Cádiz, Departamento de Filología Inglesa. CASEM -Campus Universitario 11510 Puerto Real, Cádiz (Spain).

Article first published online: 27 July 2015.

Article published online with DOI added: 5 April 2016

Revista de Lenguas para fines específicos is licensed under a Creative Commons ReconocimientoNoComercial-SinObraDerivada 4.0 Internacional License. 


\title{
Foreign language learning needs in higher education: Reasons for convergence and accountability
}

\author{
Ana Bocanegra-Valle ${ }^{1}$ \\ Universidad de Cádiz (Spain)
}

\begin{abstract}
Needs analysis is a relevant issue in language teaching as its final aim is to enhance the language learning process by setting realistic course objectives. This paper briefly reviews past and present approaches to the concept of "needs" and "needs analysis" in foreign language $(\mathrm{FL})$ methodology with particular reference to the higher education context and the post-Bologna reform. It discusses the complex interplay of addressing target and learning FL needs by gathering data from different stakeholder groups and making use of different data collection instruments. Then, it explores current trends in needs analysis research and explains how "competences" and "profiling" have surpassed "needs" and "needs analysis" in the educational systems under the European Space of Higher Education. Last, this study addresses the implications of adopting a more critical, quality-driven approach to FL needs analysis with a view to attaining a more participatory and accountable higher education.
\end{abstract}

Keywords: needs analysis, teaching English as a foreign language, European Space for Higher Education, Common European Framework, quality assurance, accountability

\section{Resumen}

El análisis de necesidades constituye un aspecto de suma importancia en la enseñanza de lenguas puesto que su fin último radica en optimizar el proceso de aprendizaje de la lengua mediante el establecimiento de objetivos realistas que permitan desarrollar un curso. En el presente trabajo se hace un breve repaso de los distintos enfoques del concepto "necesidades" y "análisis de necesidades" en el contexto de una metodología de lenguas extranjeras y se presta especial atención al contexto de la educación superior tras la

\footnotetext{
Corresponding author - Universidad de Cádiz, Departamento de Filología Inglesa. CASEM Campus Universitario 11510 Puerto Real, Cádiz (Spain).

Email: ana.bocanegra@uca.es
} 
implantación de los acuerdos de Bolonia. A continuación se estudia la compleja interrelación de concretar las necesidades meta y de aprendizaje de una lengua extranjera a partir de diferentes participantes en el proceso de enseñanza-aprendizaje y utilizar diferentes instrumentos para la recolección de datos. Seguidamente se examinan las últimas tendencias en la investigación relativa a los análisis de necesidades y se explica cómo los conceptos de "necesidades" y "análisis" han dejado paso a los de "competencias" y "elaboración de perfiles" en el marco del Espacio Europeo de Educación Superior. Por último, se abordan las implicaciones que conllevaría adoptar un enfoque más crítico y basado en principios de calidad con vistas a alcanzar una educación superior más participativa y responsable.

Palabras clave: análisis de necesidades, enseñanza de inglés como lengua extranjera, Espacio Europeo de Educación Superior, Marco Común Europeo, garantía de calidad, responsabilidad social

\section{Introduction}

There is a wealth of literature on the construct of "needs" and "needs analysis" in foreign language (FL) pedagogy, and more particularly within the fields of English for academic purposes (EAP) and English for specific purposes (ESP) instruction. The term "needs" covers "learners' goals and backgrounds, their language proficiencies, their reasons for taking the course, their teaching and learning preferences, and the situations they will need to communicate in (...), what learners know, don't know or want to know" (Hyland, 2006, p. 73); and "needs analysis" (or "needs assessment") is the process of establishing what these particular needs are so as to define and develop a sensible language curriculum. This means first identifying the learning needs of students, then translating these needs into objectives and next using them as "the basis for further development of teaching materials, learning activities, tests, program evaluation strategies, etc" (Brown, 2009, p. 269).

This study examines the evolution of "needs" and "needs analysis" since the publication of Munby's (1978) work and how these have changed its focus (from target situation communicative needs to learners' and learning needs) and taken into account the active participation of other relevant stakeholders in the education process. It explores the latest trends in needs analysis research with particular attention to task-based analysis and the FL profiles in the Common European Framework of References for Languages document. As a way of conclusion it points to accountability and quality as two important drivers in current higher education and discusses the contribution of needs analysis to attain the desired changes in this respect. 


\section{An overview of "needs" and "needs analysis"}

Needs analysis has a long history and since the 1970s it has evolved significantly redefining its focus from plain descriptions of sentence patterns, grammar and vocabulary to be learnt to a growing interest on communicative purposes, learning characteristics and teaching contexts (Upton, 2012). As Basturkmen (2013) explains, the practice of needs analysis has changed over time, the scope of investigation has widened, the data collection methods have become more varied, and "[t]he focus of investigation has been expanded from a relatively narrow investigation of the linguistic requirements of the target situation to a wider investigation that also includes investigation of needs related to learner factors and teaching context" (p. 4215).

Munby's (1978) seminal work and his proposal of a "Communication Needs Processor" set the first framework for a systematic analysis of needs in FL learning. The purpose of this processor was to "take account of the variables that affect communication needs" (p. 32), and provide a profile of needs leading to the establishment of a set of communicative competences to be met in the language course. Munby's approach was based on the language needs derived from a target situation (target needs) and somehow set learners aside in the teaching/learning process. Munby's (1978) targetsituation analysis was soon challenged by Richterich and Chancerel's (1980) present-situation analysis. This time the focus of the debate was placed on the learners themselves, at least initially, because learners' language levels were identified at the beginning of the course with the data either provided directly by the learners ("subjective" or "felt needs") or based on teachers' observations and/or intuitions ("objective" or "perceived needs").

A way forward on needs analysis was Hutchinson and Waters' (1987) learning-centred approach. These scholars identified two main categories of needs: "target needs" (or what learners need to do in a target situation), and "learning needs" (or what learners need to do in order to learn). Likewise, target needs embraced three related concepts: "necessities", or what learners need to know in order to perform efficiently in a target situation (much in line with Munby's target needs); "wants", or what learners believe that they ought to know in order to perform efficiently in the target language; and "lacks", or the gap between learners' attained and target language competence.

Hutchinson and Water's (1987) inclusive approach put an end to the discussions on the multiple meanings of "needs" and has since then been established as a reference framework for the terminology and concepts 
related to needs and needs analysis in FL research. It is evident that "[n]eeds is actually an umbrella term" (Hyland, 2006, p. 73) that brings together many inter-related concepts; however, these, if examined at the same time, may provide an assessment with inconsistent outcomes. This is the case of the study by Liu et al. (2011), who analysed the perceived needs of Taiwanese tertiary students and found that they had identical necessities, lacks and wants regarding speaking ("answer questions in conferences"), reading ("read English textbooks") and writing ("write English theses") skills but unlike necessities, lacks and wants regarding listening skills: "listen to English questions in academic fields", "listen to English terminologies", and "listen to English questions in academic fields" were respectively identified as a listening necessity, want and lack in an English language course.

A renovated trend in needs analysis is the task-based analysis approach that takes "task" as the main unit of assessment (Long and Crookes, 1993) and as the "natural unit[s] around which to organize communicative classroom lessons" (Long, 2013, p. 3570). "Tasks" also stand for "the kinds of activities that learners want to or have to be able to do with the new language" (Van Avermaet and Gysen, 2009, p. 144). There are three levels of task analysis according to Long $(2000,2013)$ : first the analysis of "target tasks" (that is, the real-world tasks that people fulfil in everyday life) based on information obtained from triangulating sources and methods (see below for an explanation about "triangulation"); after this, representative samples of language use are identified and target tasks are then classified into "task types" which establish the baseline for designing a course; and last, "pedagogic tasks" (or target tasks modified for pedagogic purposes) have to be developed to accomplish the course objectives. In Flowerdew's (2013) terms, this reorientation to task-based needs reflect "the dynamic qualities of the target discourse, thus revealing more than static, product-oriented textbased analyses" and therefore foster "a more holistic analytical syllabus" ( $p$. 328). In line with the holistic, action-oriented and qualitative character of this approach to needs assessment, task-based needs analysis has been labelled as "second generation needs analysis" by Huhta et al. (2013) - an issue that will be further discussed in relation to the tenets of the Common European Framework.

Besides Longs' publications, one of the first studies that have seriously considered the contribution of a task-based approach to needs analysis in a tertiary FL programme is that by Chaudron et al. (2005), who conducted a task-based needs assessment for 84 students enrolled in Korean classes at the University of Hawai'i. Likewise, empirical research was conducted to 
investigate the learning needs of about 200 adult learners of Dutch as a second language in order to prepare them to function well in language use situations that were relevant to their needs (Van Avermaet and Gysen, 2009). In a similar vein, the accounts by Lambert (2010) of the types of English language tasks faced by undergraduates to attain positions in business and education well provide a heuristic framework and procedures for task-based needs analysis projects in higher education English-language programmes.

An efficient assessment of needs should involve different sources of information (i.e. informants) and data should be gathered from the use of a variety of research techniques and instruments. Before setting up a needs analysis project it is important to select who our informants will be and what instruments we shall be using to gather relevant data. In the particular context of higher education, and following Robinson's (1991) terms, these might include undergraduates and graduates, pre-service and in-service learners (who will furnish the assessment with "micro-level needs"), members from the educational institution or institutional representatives (who will provide "meso-level needs") and society/employers (who will help to identify "macro-level needs"). Among others, data collection or gathering techniques may include (direct mail, online, closed-item, open-item, etc) questionnaires, (guided, open-questions) interviews, observations of (student, university staff, in-service professionals, etc) interactions, analysis of (oral, written) language use in the target situation, samples of discourse texts, employment records, reflective journals, performance tests, or observations of learners simulating target situation tasks. The use of questionnaires alone or supplemented with interviews has been identified as the most common needs analysis instrument so that it is not rare to find analysts "interviewing a subset of respondents who completed a questionnaire, or developing a set of questionnaire items from information collected in interviews" (Basturkmen, 2010 , p. 31). The use of multiple sources of information and data (i.e., the "triangulation" of sources and methods) endorse the needs analysis procedure with multiple perspectives that contribute to validating its findings as well as enriching its final outcome.

A good example of how different groups of participants enhance a needs analysis project is Chan (2001) who surveyed 701 undergraduates from all departments at Hong Kong Polytechnic, 47 teachers from the English department and some non-English department programme coordinators, and interviewed a group of respondents from each of these three groups. Also, an illustrating example of how different techniques and sources of information can be combined to produce a major research instrument in 
needs analysis may be found in Lambert (2010). Lambert conducted a taskbased needs analysis among university learners enrolled in an English language programme (including EFL and ESP) and highlighted the importance of multiple rounds of data collection by using five sources of information and data gathering instruments: extant job placement records in the Office of Student Affairs; interviews with two experienced informants; an open-item direct-mail survey of graduates over the five-year period preceding the study; a follow-up email survey of a sub-group of respondents to the first survey; and a closed-item direct-mail survey of graduates over the 25 -year period preceding the study.

Last, needs analysis is a dynamic process that may evolve over time. An illustrating example for this is Hyland (1997) and Evans and Green (2007). In 1997 Hyland surveyed 1,619 undergraduates at five English-medium universities in Hong Kong with the aim of investigating their major difficulties with the language and their perceptions about the importance, value and challenges of English for tertiary study. The study revealed that the surveyed undergraduates "believe English support classes and competence in English are important to successful study and that they may even be as important as subject knowledge" and also that "students do not feel their English is sufficient to achieve academic success" (p. 79). A decade later Evans and Green (2007) surveyed 4,932 undergraduates from the same Hong Kong higher education context with a view to revisiting the question posed by Hyland (1997). These authors' results substantiated and extended Hyland's previous findings but, more importantly, they found other issues related to course and materials design in need of redefinition so as to match the changes in Hongkongnese tertiary education: receptive and productive vocabulary poses a major problem, grammatical resources do not meet the challenges of academic assignments, or inadequate basic language competence leads to lack of confidence when attempting to perform complex linguistic tasks.

\section{A discussion of research trends}

Needs analysis is not exempt from criticisms and concerns (for an overview of these see Basturkmen, 2006, p. 19-20; Belcher, 2009, p. 3-10; Basturkmen, 2013, p. 4213-15; or Bocanegra-Valle, in press), and although many publications already provide insights into specific needs in specific contexts based on empirical research (Taillefer, 2007; Van Avermaet and Gysen, 2009; Breeze, 2014; to name a few), there is still a general tendency in the literature 
to address the issue from a methodological perspective providing pointers on how to conduct valid and efficient needs assessments.

An inquiry into the research published on language needs assessment in higher education shows that works with a broad macro-skill orientation feature prominently on the literature. Examples spread across the globe but conclusions are often common: studies signpost the little presence of listening and speaking skills in higher education courses and claim a more prominent role. Ferris (1998) surveyed 768 English as a second language (ESL) students and 206 ESL instructors at three tertiary institutions in USA and found that courses placed a heavier focus on literacy skills to the detriment of aural/oral skills. Chan (2001) arrived at a similar conclusion: respondents claimed that priority should be placed on improving aural/oral skills for conferences and seminars particularly, but also on building discipline-specific vocabulary, raising student's confidence and motivation in language learning. By the same token, both Karimkhanlouei (2012) and Chowdhury and Haider (2012) claimed more emphasis on aural/oral skills after respectively investigating the needs of 41 Iranian medical students in mastering different skills of language in the academic context, and how far English university courses were meeting the needs of 40 Pharmacy students in Bangladesh.

In the European context, Taillefer (2007) assessed the professional needs of Economics graduates so as to encourage reflection on curriculum and pedagogical issues. He surveyed 126 postgraduates, 125 undergraduates, 28 language teachers and 30 economics teachers by means of a 30-item questionnaire and identified an urgent need to link language learning targets in higher education to the profession, particularly (and again) regarding oral communication, which was perceived as implying the most difficult skills (i.e. aural/oral). The regrets he gathered in his survey are self-illuminating and may well echo the same concern in other (at least European) countries: "the handicapping insistence on grammatical perfection to the detriment of oral fluency" or "frustration at having spent nine years in secondary school and university studying a foreign language and being unable to communicate" ( $p$. 150). More recently, Breeze (2014) focused on the needs pertaining to listening skills in Law and Medicine courses taught in the context of Englishmedium instruction (EMI) in a Spanish university. By means of questionnaires and structured and semi-structured interviews conducted among 83 Law and 63 Medicine students, this scholar listed a set of "difficulties" which impact on learning performance and, thus, point at the most immediate academic needs in this context: "building up learners' note-taking skills", "coping with high speed of delivery and unfamiliar accents", "devising strategies to 
improve concentration in English over long stretches of time", or "gaining familiarity with key subject-specific terminology".

Needs have also been examined at the micro-level so that particular language and learning needs have been identified and ranked in terms of the most and least relevant when teaching higher education students. An early study on this regard is Basturkmen (1998) who identified the ten most important language-based tasks for study as stated by faculty and students of English at Kuwait University: "reading textbooks", "writing up lab reports/assignments", "following lectures", "reading instructions for labs and assignments", "reading course and lecture handouts", "note taking in lectures", "listening to presentations and participating in discussion", "preparing projects" and "preparing answers to questions from textbooks". Another example is Johns (2009), who identified a genre awareness-based set of needs for tertiary undergraduates in an academic English literacy class: "read a variety of texts for a variety of purposes", "analyze a variety of prompts", "write short, well-crafted papers responding to prompts", "integrate sources into their papers and discussions", "accurately paraphrase, summarize, and interpret the readings", "build precise academic vocabulary", "research literacies", and "reflect frequently". More recently, Atai and Nazari (2011) have provided a profile of present and target reading comprehension needs of Iranian undergraduate students of English in a health information management course and identified the following sub-skills as (very) importantly perceived: "skimming texts", "using bilingual general dictionaries", "scanning texts", "knowledge of HIM [health information management] terminologies", "guessing meanings of words using the context", and "understanding main ideas".

Two contentious issues concern to whose needs (only learners' needs?) should be the target of a needs assessment, and to what extent teachers, learners or other stakeholders are the best providers of data for needs analysis purposes. Most needs analysis reports examine the students' language needs and gather data from the students themselves, either exclusively or in combination with a group of teachers or academic-related staff but works like Nunan (1988) well serve to illustrate to what extent learners' and teacher's perceptions of pedagogical needs in a FL classroom may differ. For some scholars like Long (2005), pre- and in-service learners tend to perform as inappropriate sources of information because even though they may know much about their work, they know "little about the language involved in functioning successfully in their target discourse domains" (p. 20). For others, there is clearly some divergence between faculty 
and students' perceptions regarding language problem areas and the relative importance of skills (Basturkmen, 1998); also, students' (perceived needs) and instructors' (expectations) responses differ dramatically in Ferris' (1998) study; in Taillefer (2007) there is discordance in perceptions of target and learning needs among the different stakeholder groups surveyed in the study; for Bacha and Bahous (2008) and Eslami (2010) faculty/instructors and students do not hold similar views of students' English ability or needs in their business courses and their perceptions about problematic areas in language programmes also differ. As Brown (2009) contends, needs analysis is "the perfect means for finding out what people are thinking and for exploring how the view of various groups are similar and different" (p. 286); hence, and as the literature attests, for a sound result the procedure should take into account the views, perceptions, goals, preferences, etc. of as many stakeholder groups as possible.

Another sensitive issue concerns the pedagogical implications for syllabus design, course planning, material development and curriculum renewal raised by a needs analysis procedure. The study of needs is "the input for course design and materials development" (Belcher, 2009, p. 7), "the first step in curriculum development" (Brown, 2009, p. 269), "the means of establishing the how and what of a course" (Hyland, 2006, p. 73), "a principal stage in course design" (Atai and Nazari, 2011, p. 30), and a prerequisite for course design but, as teachers and learners gain increased understanding of the situation, it will also play an important role in refining the course and redefining procedures and concepts, particularly once initiated and while running (Basturkmen, 2010). Because course designers have a "needsidentifying responsibility" (Belcher, 2009, p. 3) and in language education such responsibility often falls upon teachers who are required to assume a variety of roles (course designer, needs analyst, materials developer, to name a few), teachers can make the most of this circumstance and use their need analysis findings to refine the course, implement changes (in syllabuses, classroom practices, materials, etc.) and enhance the general curriculum. An interesting study on this regard is that reported in Alalou (2001), who targeted three higher education language programmes (Spanish, French and German as a FL in a liberal arts college setting in New York), and surveyed 525 students to find out similarities and differences in language needs among students in these three programmes and to what extent such perceived needs matched the current objectives and content of their respective language courses. Also in line with these pedagogical implications and for the particular case of EAP courses, Bocanegra-Valle (in press 2015) provides clear pointers for future work on the basis of current research. 


\section{From "needs" to "profiles" under the European Higher Education Area scheme}

Munby's (1978) work, as discussed in an earlier section, set a landmark in the fields of communicative language teaching and needs analysis because the individual learner was taken a starting point for devising the communicative needs of learners in their targeted situations (Hall, 2013). Munby (1978) and Richterich and Chancerel (1980) were the forerunners to promote an approach to language teaching in which the target communicative needs of the students had a pivotal role and, accordingly, they set the foundations for many of the Council of Europe's methodological principles regarding FL teaching across Europe.

The Common European Framework of References for Languages (CEFR) (Council of Europe, 2001) is at present a powerful instrument for attaining convergence in European FL higher education and developing language syllabuses and curriculum guidelines in accordance with the requirements of the European Higher Education Area (EHEA). The CEFR is, as pointed out by Flowerdew (2013), a "language planning initiative in Europe [that] seems to take us full circle back to the major aim of Richterich and Chancerel's needs analysis of the 1970s - to ensure some degree of standardization of language teaching across countries" (p. 341).

The CEFR contains references to the needs of learners ("real needs", "communicative needs", "specific needs", "target needs", "learner needs" or even "motivations" are synonyms used throughout the text to refer to these) and of society (i.e., the needs of a multilingual and multicultural Europe). There is also some reference to professional or target needs to be diagnosed and covered by the lists of specifications and scales contained in the CEFR. The Council of Europe (2001) explicitly encourages language learning stakeholders "to base their work on the needs, motivations, characteristics and resources of learners" (p. notes for the user), and this means providing answers to these three questions: "What will learners need to do with the language?" (i.e., leaner needs), "what do they need to learn in order to be able to use the language to achieve those ends?" (i.e., learning needs) and "what makes them want to learn?" (i.e., target needs).

The CEFR, and particularly the self-assessment grid, is a useful tool for learners to define their needs and express "what they can already do and what their objectives are" (Heyworth, 2007, p. 15) and, more importantly, a necessary point of departure "for setting objectives and for comparing and accrediting quality" (Heyworth, 2013, p. 287). The CEFR provides a descriptive 
framework based on a competence model with agreed levels of proficiency which combines values or attitudes, knowledge, understanding and skills. This is particularly important because, as Heyworth (2013) explains and shall be discussed in a later section, descriptive frameworks are needed "in order to establish quality criteria and standards" (p. 298).

The terms "needs" and "competences" permeate the CEFR; however, needs analysis is an angle that has not been covered herein (Coste, 2007). The Council of Europe has provided a scaling of language competences that aim at facilitating the specification of learning objectives against varying degrees of achievement and, most importantly, that stem from the analysis of the diverse communicative and target needs of learners. How and when this needs analysis has been carried out, who the participants were, or what dataeliciting methods were used are issues which, at least to this author's knowledge, remain unclear. This fact underscores that, more often than not, "[t]he exploration of learners' language learning needs is often circumvented. Even if it is explicitly acknowledged that individuals may have proper learning needs in mind" (Van Avermaet and Gysen, 2009, p. 144).

In the CEFR "competences" are defined as "the sum of knowledge, skills and characteristics that allow a person to perform actions" (Council of Europe, 2001, p. 9); these may be "general competences" (not specific to language but required for any action to be taken) and "communicative language competences" (which assist individuals in taking actions using linguistic means). Hence, competences perform here as the whole group of language learning and target needs to be fulfilled so as to accomplish certain tasks in a FL.

The CEFR reference levels of language proficiency (from A1 - Basic User, Breakthrough, to C2 - Proficient User, Mastery) and the corresponding analytic scales add a vertical dimension so that it is possible to profile current position and target needs, map learning space, gauge the fulfilment of needs, identify leaner's achievements and "provide a diagnosis of what needs to be covered to get there" (p. 38). Profiling seems to be a natural practice to control the workable diversity of needs of a large group of learners because even though listing individual needs may be theoretically sustainable, it will be more affordable and practicable to recluster "the seemingly infinite diversity of individuals' language learning needs" into a "workable number of needs profiles" (Vam Avermaet and Gysen, 2009, p. 144).

The literature contains some examples of needs analyses conducted under the framework of the CEFR in higher education. With the aim of investigating 
the language needs (more particularly, "language wants") of English majors, Kormos, Kontra and Csölle (2002) surveyed 279 students undergraduates and 80 graduates from all Hungarian universities (six universities in all) with the aid of a 96-item questionnaire informed by the CEFR and later piloted and validated with think-aloud interviews and test-retest reliability analysis. The conclusions reached refer to the use of English mainly with study purposes ("listen to lectures", "take notes", "listen to other students' presentations", "express their opinion verbally" or "use dictionaries") against a surprisingly lesser use in the private domain ("watching news or films", "reading texts on the Internet", "writing e-mails", "using electronic games", "conversation with native speakers", etc). Another striking conclusion is that after graduation production skills in English are used more frequently than during university studies ("when expression opinion", "in job-related conversations", "reading texts on the Internet", etc).

In a similar vein, Taillefer (2007) explored the language needs of students of social sciences at Toulouse University and based his analysis of target and learning needs on the levels of competence described in the CEFR. More particularly, he investigated the perceptions of "the context of professional language use (real and projected), the level of receptive and productive competence deemed necessary for professional life (...) the importance of language in finding a first job and optimal organisation of university language training" (p. 141). For these purposes, the assessment instrument employed was a basic questionnaire developed against the six-point CEFR scale and aimed at students, economics teachers, language teachers and graduates. Taillefer's (2007) main conclusions pinpoint an institutional redefinition of the notion "mastery" of a FL in terms of priority skills and levels of competence, greater awareness of the question of multilingualism, the integration of disciplinary and language components, the integration of language resource centres and the concept of learner autonomy, and greater coherence for the European Credit Transfer System (ECTS) credits. The questionnaire developed for the four macro-skills and contained in an appendix to the article may well serve as a guide to other researchers investigating target and learning needs in the light of the levels of competence in a FL as described by the Council of Europe's CEFR.

A challenging view is that offered by the Language Centre at the Finnish University of Jyväskylä, which has set the "General proficiency level assessment guidelines for all languages taught at the academic level" based on the CEFR and preceded by a prior identification of core skills - that is, a survey of language and communication needs to be met by higher education 
students in the labour market. An example for the A2 guidelines is given in Table 1.

\begin{tabular}{l|l}
\hline Spoken interaction & $\begin{array}{l}\text {... can cope with simple social encounters and routine-like } \\
\text { conversations }\end{array}$ \\
\hline Spoken production & $\begin{array}{l}\text {... can describe his/her student career and career choice using basic } \\
\text { terminology of his/her own field } \\
\text {... can ask for attention from listeners } \\
\text {... can formulate and use simple phrases and structures } \\
\text {... can pronounce so that s/he is usually understood, but at times } \\
\text { must repeat in order for listener to understand }\end{array}$ \\
\hline Reading & $\begin{array}{l}\text {... can read very short of popularized texts in his/her own field in the } \\
\text { target language and, using dictionaries and other kinds of reference } \\
\text { materials, can identify some main points in the text }\end{array}$ \\
\hline Writing & $\begin{array}{l}\text {... can write short and simple messages and very basic descriptions } \\
\text { of e.g. personal experiences }\end{array}$ \\
\hline Communication & $\begin{array}{l}\text {... can ask for his/her turn in a conversation } \\
\text {... can ask for clarification in a simple manner } \\
\text { strategies }\end{array}$ \\
\hline
\end{tabular}

Table 1: Proficiency level assessment guidelines for level A2 at the University of Jyväskylä

(https://kielikeskus.jyu.fi/opetus/eng/anti/proficiency-level-descriptions-1/assessmentcriteria).

It must be emphasized that the CEFR adopts an action-oriented approach in which actions "performed by one or more individuals strategically using their own specific competences to achieve a given result" (Council of Europe, p. 9) -that is, "tasks"- are central to language learning. In line with this, a key project that very successfully establishes the link between needs analysis and the CEFR guidelines is the "Common European Framework (CEF) Professional Profiles" (Huhta et al., 2013), developed thanks to the funding of a Leonardo Da Vinci project and the partnership of six European countries (Bulgaria, Finland, Germany, Hungary, the Netherlands and Poland).

In the belief that the practices of traditional needs analysis are not sufficient, the CEF Professional Profiles develop an action-oriented task-based approach to needs analysis that matches the CEFR principles and can be applied to the syllabus design and curriculum development of higher education courses for workplace communication. The tasks identified are those arising from the needs of professionals in modern enterprises and organisations (i.e., workplace target needs) and the needs of society. Huhta et al. (2013) have used a combination of quantitative and qualitative methods to identify the learning needs of individuals, teachers and professionals against the task-oriented framework of the CEFR and create professional, field-specific language proficiency profiles for technology, business, health 
and social care, and law. The categories and domains from the CEFR were applied to produce a set of profiles for the four professional fields, each containing six strands of information: (i) target profession (including training, qualifications and specialisation); (ii) target occupational field (like typical occupations, job descriptions, or companies); (iii) context (which includes locations, persons, communicative situations or texts); (iv) most frequent situations beyond everyday professional encounters; (v) most demanding situations as well as critical moments for the professionals; (vi) narrative accounts or insights into the experience of professionals in the domain (snapshots). Huhta et al. (2013) demonstrate that it is possible to carry out an effective needs analysis from the tenets developed throughout the CEFR, taking into account a multiple perspective and gathering information from all the stakeholders involved - i.e., learners, teachers, experienced professionals, and companies.

\section{By way of conclusion: Towards a more participatory higher education}

By the end of 2005, when an incipient financial crisis was beginning to strike many parts of the world (with severe consequences in some European countries like Spain), Michael Long was already claiming more accountability in public life, and particularly in FL education. "In a era of shrinking resources", he stated, "adults with serious academic, occupational, vocational, or 'survival' needs for functional L2 proficiency (...) are increasingly dissatisfied with lessons, materials and methodology developed for someone else or for no-one in particular" (Long, 2005, p. 19). In order to respond to such situation, this scholar continued, FL educators should base more of their courses "on the findings of surveys of learner needs" (Long, 2005, p. 19).

In their roles of syllabus designers and course developers, FL teachers (together with other university and professional stakeholders) have been found accountable for their students' learning outcomes. In this regard, some literature in FL pedagogy has become very critical, pointing at a more participatory and negotiated education that sees students as active agents (Benesch, 2001) and claiming more awareness of the importance of needs assessments, which implies "a state of mind open to external evaluation and the ability and willingness to question traditional values and modes of operation" (Taillefer, 2007, p. 148-149). From this reasoning, it can be inferred that terms such as "criticism", "participation", "negotiation", "accountability", "evaluation" or "questioning" anticipate the integration of a "quality culture" (Bollaert et al., 2007; Muresan and Ursa, 2014) in higher education that "places students at the centre" (Harvey, 2007, p. 81). 
Quality assurance is concerned with, although not limited to, the identification of the needs of learners and any other educational programmes' beneficiaries (i.e., stakeholders) and how well course programmes respond to such needs. In evaluating a course, the evaluator might present her/himself "as an objective stance that can identify the needs of the target group and those of the society and uses those needs to judge the objectives of the programme" (Cerkez, 2010, p. 113). Quality assurance methodology should be more "client-responsive" (Cerkez, 2010, p. 116) and assist in improving the overall educational programme. In quality management, students and other parties concerned are often referred to as "clients" (also "customers") and the quality assurance and accountability measures in effect ensure that the clients' needs and expectations are met (Amaral, 2007). Following Heyworth's (2013) terms, in a higher education setting the three levels of parties concerned could be categorized as "primary clients", who pay for the service (i.e., students); "secondary clients", who are also consumers of the service in a different way (i.e., teachers, administrators, etc.); and "unwitting clients", who may be affected by the delivery of the service (employers, society, etc.). Similarly to organizations and companies, if the principles of quality management are to be applied in a higher education setting, it is necessary to implement the necessary mechanisms that will lead to the identification and satisfaction of the client needs "because the client's satisfaction provides proof for the quality" (Borza and Crişan, 2012, p. 29).

The international association EAQUALS (Evaluation and Accreditation of Quality in Language Services) comprises language education institutions and organisations and aims at promoting and safeguarding high quality in language teaching/learning. EAQUALS have published several working papers that provide the framework, guidance and tools for bringing language teaching/learning in line with quality assurance principles. Most of those documents contain references to learner/target needs and needs analysis procedures as a main area in supporting the learning process and the teaching profession. For instance, language teachers' values and attitudes are promoted in terms of language needs analysis and course planning:

- A concern with identifying the learning needs and wants of all learners, and a conviction that methodical planning will lead to greater learner achievement and satisfaction.

- A readiness to consult learners and involve them in the planning process, prompting feedback and adapting activities in response to this. 
- A realisation that planning needs to be flexible and that plans should be modified in the light of the learning process and learners' needs.

- An appreciation that there should be a clear progression from one lesson to another with reference to the planned learning outcomes, and that remedial work is likely to be necessary to address areas where language development is progressing more slowly.

- Critical awareness of a range of possible resources and their sound exploitation with reference to learners' level. (EAQUALS, 2013, p. 8)

The Inspection Scheme and Reference Guide for Institutions (EAQUALS, 2011) recognises that "course participants' needs and learning" is one of the main focus points in the inspection process: learners' needs are diagnosed, learning objectives have to be adapted to learners' needs, services to course participants are adequate and correspond to their needs, learners are involved in reviewing their needs and wishes and what has been planned and done.

Muresan (2011), Bardi and Muresan (2012) and Muresan and Ursa (2014) have investigated the links between needs analysis and quality principles for the particular case of teaching English with specific and academic purposes at the tertiary level. In Bardi and Muresan (2012) needs analysis dynamics appear as a key component in a quality-based approach to language teaching and a driver for adopting decisions during and after the course (see Bocanegra-Valle, in press, for a detailed discussion of this proposal). In the latest study the changes in learner needs and expectations are explored together with an examination of to what extent addressing student needs can, among others, enhance quality standards in university contexts: needs analysis, combined with a diagnostic test of initial learner competences (or placement testing) and with learner self-assessment (in the terms described in the EHEA documents), become "the foundation for syllabus design, linked with on-going assessment and self-assessment of progress, inviting studentfeedback and end-of-course assessment in relation to the starting point" (Muresan and Ursa, 2014, p. 136).

In his excellent review article of 2013, Frank Heyworth discussed in depth the applications of quality management in the particular case of language education, claimed more quality awareness and commitment, and encouraged more research in the field. It is precisely in this regard that this study has tried to reflect the complexities that the constructs "needs" and "needs analysis" entail in the context of FL tertiary education, showing competence profiling and quality procedures as a way forward to strengthen 
convergence and accountability in FL higher education, particularly across Europe.

\section{About the author}

Ana Bocanegra-Valle is a Senior Lecturer at the University of Cadiz (Spain). Her main research interests include English for scholarly publishing, ESP/EAP methodology (needs analysis and learning strategies), and Maritime English as a particular branch of ESP. She was former editor-inchief of the LSP-related journal Ibérica (ISSN 1139-7241) and is at present associate editor of ESP Today - Journal of English for Specific Purposes at Tertiary Level (ISSN 2334-9050).

\section{Acknowledgements}

I am grateful to the external reviewers and Patricia Arnaiz, invited editor to this volume for their suggestions and guidance.

\section{LFE Article history}

Paper received: $26^{\text {th }}$ February 2015

Paper received in revised form and accepted for publication: $19^{\text {th }}$ March 2015

\section{References}

Alalou, A. (2001). Reevaluating curricular objectives using students' perceived needs: The case of three language programs. Foreign Language Annals, 34(5), 453-469.

Amaral, A. (2007). Higher education and quality assessment. The many rationales for quality. In L. Bollaert et al. (Eds.), Embedding Quality Culture in Higher Education, EUA case Studies 2007 (pp. 6-10). <http://www.eua.be/Libraries/EQAF_2010/EUA_QA_Forum_publication _1.sflb.ashx> 
Atai, M. R., \& Nazari, O. (2011). Exploring reading comprehension needs of Iranian EAP students of health information management (HIM): A triangulated approach. System, 39(1), 30-43.

Bacha, N. N., \& Bahous, R. (2008). Contrasting views of business students' writing needs in an EFL environment. English for Specific Purposes, 27(1), 74-93.

Bardi, M., \& Muresan, L. (2012). Student perceptions of programme quality - A tool for improvement. Quality Review for Higher Education, 4(1), 14-22.

Basturkmen, H. (1998). Refining procedures. A needs analysis project at Kuwait University. English Teaching Forum, 36(4), 2-18.

Basturkmen, H. (2006). Ideas and Options in English for Specific Purposes. Mahwah, NJ: Lawrence Erlbaum.

Basturkmen, H. (2010). Developing Courses in English for Specific Purposes. New York: Palgrave Macmillan.

Basturkmen, H. (2013). Needs analysis and syllabus design for Language for Specific Purposes. In C. A. Chapelle (Ed.), The Encyclopedia of Applied Linguistics (pp. 4209-4217). Oxford: Blackwell.

Belcher, D. (2009). What ESP is and can be: An introduction. In D. Belcher (Ed.), English for Specific Purposes in Theory and Practice (pp. 1-20). Ann Arbor, MI: University of Michigan Press.

Benesch, S. (2001). Critical English for Academic Purposes: Theory, Politics, and Practice. Mahwah, NJ: Lawrence Erlbaum.

Bocanegra-Valle, A. (in press). Needs analysis for curriculum design. In K. Hyland \& P. Shaw (Eds.). Handbook of English for Academic Purposes. Abingdon, Oxford: Routledge.

Bollaert, L. et al. (Eds.) (2007), Embedding Quality Culture in Higher Education, EUA case Studies 2007. <http://www.eua.be/Libraries/EQAF_2010/EUA_QA_Forum_publication_1.sflb.ashx>

Borza, A., \& Crişan, C. (2012). Employers' expectations: Competencies of entrepreneurs versus competencies of graduates of higher education. Quality Review for Higher Education, 4(2), 29-40.

Breeze, R. (2014). Identifying needs in English-medium university courses. In R. Breeze, C. Llamas Saiz, C. Martínez Pasamar \& C. Tabernero Sala (Eds.), Integration of Theory and Practice in CLIL (pp. 143-159). Amsterdam/New York: Rodopi.

Brown, J. D. (2009). Foreign and second language needs analysis. In M. H. Long \& C. J. Doughty (Eds.), The Handbook of Language Teaching (pp. 269-293). West-Sussex: WileyBlackwell.

Cerkez, M. (2010). Defining quality in higher education - Practical implications. Quality Review for Higher Education, 2(2), 109-119.

Chan, V. (2001). Determining students' language needs in a tertiary setting. English Teaching Forum, 39(3), 16-27. 
Chaudron, C., C. J. Doughty, Y. Kim, D. -K. Kong, J. Lee, Y.-G. Lee, M. H. Long, R. Rivers \& K. Urano (2005). A task-based needs analysis of a tertiary Korean as a foreign language program. In M. H. Long (Ed.), Second Language Needs Analysis (pp. 225-261). New York, NY: Cambridge University Press.

Chowdhury, T.A., \& Haider, Md.Z. (2012). A need-based evaluation of the EAP courses for the pharmacy students in the University of Asia Pacific (UAP), Bangladesh. Asian Social Science, 8(15), 93-107.

Coste, D. (2007). Contextualising Uses of the Common European Framework of Reference for Languages. Council of Europe Language Policy Division. <http://www.coe.int/t/dg4/ linguistic/Publications_EN.asp - P115_3863>

Council of Europe (2001). Common European Framework of Reference for Languages: Learning, Teaching, Assessment. Language Policy Unit. <http://www.coe.int/t/dg4/linguistic/source/ framework_en.pdf> [02/09/2014]

EAQUALS (2011). Inspection Scheme version 6.2 - Reference Guide for Institutions. <http://clients. squareeye.net/uploads/eaquals2011/documents/Reference_Guide_to_EAQUALS_Inspecti on_Scheme_6_2_February2011.pdf>

EAQUALS (2013). The EAQUALS Framework for Language Teacher Training and Development. $<$ http://clients.squareeye.net/uploads/eaquals/EAQUALS_TD_FRAM_November_2013. pdf>

Eslami, Z. R. (2010). Teachers' voice vs. students' voice: A needs analysis approach to English for Academic Purposes (EAP) in Iran. English Language Teaching, 3(1), 3-11.

Evans, S., \& Green, C. (2007). Why EAP is necessary: A survey of Hong Kong tertiary students. Journal of English for Academic Purposes, 6(1), 3-17.

Ferris, D. (1998). Students' views of academic aural/oral skills: a comparative needs analysis. TESOL Quarterly, 32(2), 289-319.

Flowerdew, L. (2013). Needs analysis and curriculum development. In B. Paltridge \& S. Starfield (Eds.), The Handbook of English for Specific Purposes (pp. 325-346). West-Sussex: Wiley-Blackwell.

Hall, D. R. (2013). Introduction. In M. Huhta, K. Vogt, E. Johnson \& H. Tulkki. Needs Analysis for Language Course Design. A Holistic Approach to ESP (pp. 1-8). Cambridge: Cambridge University Press.

Harvey, L. (2007). Quality culture, quality assurance and impact. Overview of discussions. In L. Bollaert et al. (Eds.), Embedding Quality Culture in Higher Education, EUA case Studies 2007 (pp. 81-84), <http://www.eua.be/Libraries/EQAF_2010/EUA_QA_Forum_publication_1.sflb. ashx $>[02 / 09 / 2014]$

Heyworth, F. (2007). Quality and people. In L. Muresan, F. Heyworth, G. Mateva \& M. Rose (Eds.), QualiTraining - A Training Guide for Quality Assurance in Language Education (pp. 721). Strasbourg: Council of Europe. 
Heyworth, F. (2013). Applications of quality management in language education. Language Teaching, 46(3), 281-315.

Huhta, M., Vogt, K., Johnson, E., \& Tulkki, H. (2013). Needs Analysis for Language Course Design. A Holistic Approach to ESP. Cambridge: Cambridge University Press.

Hutchinson, T., \& Waters, A. (1987). English for Specific Purposes. A Learning-centred Approach. Cambridge: Cambridge University Press.

Hyland, K. (1997). Is EAP necessary? A survey of Hong Kong undergraduates. Asian Journal of English Language Teaching, 7, 77-99.

Hyland, K. (2006). English for Academic Purposes. An Advanced Resource Book. Oxon: Routledge.

Johns, A. (2009). Tertiary undergraduate EAP: Problems and possibilities. In D. Belcher (Ed.), English for Specific Purposes in Theory and Practice (pp. 41-59). Ann Arbor, MI: University of Michigan Press.

Karimkhanlouei, G. (2012). What do medical students need to learn in their English classes? Journal of Language Teaching and Research, 3(3), 571-577.

Kormos, J., Kontra, E. H., \& Csölle, A. (2002). Language wants of English majors in a non-native context. System, 30(4), 517-542.

Lambert, C. (2010). A task-based needs analysis: Putting principles into practice. Language Teaching Research, 14(1), 99-112.

Liu, J-Y, Chang, Y-J., Yang, F-Y., \& Sun, Y-C. (2011). Is what I need what I want? Reconceptualising college students' needs in English courses for general and specific/academic purposes. Journal of English for Academic Purposes, 10(4), 271-280.

Long, M. H., \& Crookes, G. (1993). Units of analysis in syllabus design: The case for task. In G. Crookes \& S. Gass (Eds.), Tasks in a Pedagogical Context (pp. 9-54). Clevedon, Avon: Multilingual Matters.

Long, M. H. (2000). Focus on form in task-based language teaching. In R. Lambert \& E. Shohamy (Eds.), Language Policy and Pedagogy: Essays in Honor of Ronald Walton (pp. 181196). Amsterdam: John Benjamins.

Long, M. H. (2005). Methodological issues in learner needs analysis. In M. H. Long (Ed.), Second Language Needs Analysis (pp. 19-76). New York, NY: Cambridge University Press.

Long, M. H. (2013). Needs analysis. In C. A. Chapelle (Ed.), The Encyclopedia of Applied Linguistics (pp. 3569-3572). Oxford: Blackwell.

Munby, J. (1978). Communicative Syllabus Design. Cambridge: Cambridge University Press.

Muresan, L. (2011). The dynamics of shared values in language education and local endeavours in times of change. In C. Pérez-Llantada \& M. Watson (Eds.), Specialised Languages in the Global Village. A Multi-Perspective Approach (pp. 47-76). Cambridge: Cambridge Scholars. 
Muresan, L., \& Ursa, O. (2014). Ingredients of a quality culture in language education - The way forward in LSP/EAP contexts. In S. Munteanu \& E. Păcurar (Eds.), Studii de diversitate culturală şi limbaje de specialitate (pp. 127-139). Cluj-Napoca: Casa Cărţii de Ştiinţă.

Nunan, D. (1988). The Learner-Centred Curriculum. Cambridge: Cambridge University Press.

Richterich, R., \& Chancerel, J.L. (1980). Identifying the Needs of Adults Learning a Foreign Language. Strasbourg: Council of Europe.

Robinson, P. (1991). ESP Today. London: Prentice Hall.

Taillefer, G. F. (2007). The professional language needs of Economics graduates: Assessment and perspectives in the French context. English for Specific Purposes, 26(2), 135-155.

Upton, T. A. (2012). LSP at 50: Looking back, looking forward. Ibérica, 23, 9-28.

Van Avermaet, P., \& Gysen, S. (2009). From needs to tasks. Language learning needs in a taskbased approach. In K. Van den Branden, M. Bygate \& J. M. Norris (Eds.), Task-Based Language Teaching. A Reader (pp. 144-170). Amsterdam. John Benjamins. 